\title{
The Preservation of Bacteria by Drying
}

\author{
BY LORD STAMP \\ The Microbiological Research Department, Porton, and \\ the British Postgraduate Medical School, London
}

\begin{abstract}
SUMMARY: A quantitative study of the survival of vegetative bacteria on drying in various suspending media led to a simple method for preserving bacterial cultures. Bacterial cells are suspended in melted nutrient gelatin containing ascorbic acid or sodium ascorbate in concentration of $0.25-0.5 \%$. Small quantities are dried over $\mathrm{P}_{2} \mathrm{O}_{5}$ at pressures of $100-300 \mathrm{~mm}$. of mercury and stored in vacuo over $\mathrm{P}_{2} \mathrm{O}_{5}$ at room temperature. A wide range of bacterial species of medical and veterinary importance was preserved by this method for 4 years. The slow decline in the number of viable organisms and the high percentage survival rate at 4 years indicate the likelihood of survival for a much longer period.

The virulence of a number of pathogenic species was successfully maintained in the dry preparation. The method might well be applied to the preservation of living vaccines.

The survival rates with Chromobacterium prodigiosum dried by this method were better than those in preparations subjected to rapid freeze-drying processes. They were, however, unsatisfactory with a few species such as Vibrio cholerae and Neisseria meningitidis.
\end{abstract}

A number of methods have been described for the preservation of stock cultures of bacteria by drying. The simplest consists in drying the organisms suspended in culture fluid or resuspended in saline, serum or blood in a desiccator in vacuo over dehydrating agents such as $\mathrm{H}_{2} \mathrm{SO}_{4}$ or $\mathrm{P}_{2} \mathrm{O}_{5}$. The suspensions are dried on sterile coverslips, filter paper, in small test-tubes, or more conveniently in sterile ampoules which can subsequently be sealed off in vacuo. Successful results with a variety of bacterial species have been reported by Heim (1905, 1907, 1922), Brown (1925, 1932), Harris \& Lange (1933), Otten (1930, 1932), Pauli (1932), and Mackie \& McCartney (1945). Some pathogens have also been preserved satisfactorily by similar drying of the spleens taken from infected animals. Others recommend freezing the bacterial suspension immediately before and during the drying process by immersing the container in an ice and salt mixture, or in a mixture of $\mathrm{CO}_{2}$ snow and glycerol placed in the desiccator (Shackell, 1909; Rogers, 1914; Swift, 1921, 1937; Morton \& Pulaski, 1938). A more elaborate freeze-drying process was developed by Elser, Thomas \& Steffen (1935) and Flosdorf \& Mudd (1935, 1938) for the preservation of biological products, including micro-organisms. In this so-called 'lyophile' process the bacterial suspension is delivered into ampoules and frozen by immersion in salt and ice mixture or $\mathrm{CO}_{2}$ snow. The ampoules are then attached to a manifold and the moisture is drawn off by means of an efficient vacuum pump, such as the Cenco-Megavac or Hyvac, and trapped by condensation in a vessel immersed in $\mathrm{CO}_{2}$ snow or by means of a chemical desiccant chamber containing anhydrous calcium sulphate. Traps containing $\mathrm{P}_{2} \mathrm{O}_{5}$ are used also to 
collect the last traces of moisture carried over. Drying is complete in a very short period and the ampoules are then sealed off in situ under high vacuum. This method is said to give the most satisfactory results, particularly with delicate organisms.

However, in little of the work published on the drying of bacteria has any attempt been made to determine systematically the conditions most favourable for survival. This can be done satisfactorily only by quantitative methods in which the percentage of organisms surviving desiccation under different conditions is accurately estimated. In this paper a study has been made on these lines of some of the factors which might be expected to influence survival (such as the use of different suspending media) and of the two methods in common use for preserving stock cultures by drying, namely, simple drying in the unfrozen state in a desiccator over dehydrating agents in vacuo, and the more rapid freeze-drying 'lyophile' process. As a result a simple drying technique has been developed and used to preserve a large number of bacterial species.

\section{METHODS}

Preparation of the bacterial suspension. The organism under test was grown on a suitable agar medium in Petri dishes or Roux bottles. The latter proved preferable in view of the lesser likelihood of contamination. In one or two experiments (e.g. with Pasteurella pestis) the suspension was made from a broth culture. The growth was removed by scraping off with a sterile glass slide or by washing off and centrifuging. The packed cells were thoroughly emulsified in the suspending medium. A wide range of concentrations of bacterial cells was used, but in most cases a thick suspension containing $5 \times 10^{9}$ to $1.5 \times 10^{10}$ organisms $/ \mathrm{ml}$. of suspending medium was used. With profusely growing organisms such as the Salmonellae, these concentrations were attained when the growth from three agar plates or one Roux bottle, grown for $24 \mathrm{hr}$. at $37^{\circ}$ on tryptic meat agar or CCY agar (Gladstone \& Fildes, 1940), was added to 2.5-10 ml. of suspending medium. In the majority of tests the suspending medium was nutrient gelatin, containing peptone (Evans, Sons, Lescher \& Webb) $1.0 \%, \mathrm{NaCl} 0.5 \%$, Lemco beef extract $0.4 \%$, and Coignet gold label gelatin $10 \cdot 0 \%$. The first three ingredients were made up double strength, the $\mathrm{pH}$ adjusted to $9 \cdot 3$ to precipitate phosphates which were removed and then readjusted to $\mathrm{pH} 7 \cdot 6$; an equal volume of a $20 \%$ solution of gelatin was then added. The medium was cleared with egg albumin, steamed for $30 \mathrm{~min}$., shaken, steamed for a further $2 \mathrm{hr}$., filtered, the $\mathrm{pH}$ adjusted to $7 \cdot 6$ and the medium autoclaved at $115^{\circ}$ for $15 \mathrm{~min}$.

Other suspending media were: fresh defibrinated horse blood, fresh sterile rabbit serum heated at $60^{\circ}$ for $1 \mathrm{hr} ., 2 \cdot 5 \%$ solution of mucin in distilled water, $2.0 \%$ solution of polyvinyl alcohol in distilled water sterilized at $100^{\circ}$. The $\mathrm{pH}$ of each was checked and adjusted when necessary to $c .7 \cdot 0$ before use. Solutions of ascorbic acid were made up in the suspending medium under test or in 
distilled water in ten times the strength required and heated to $100^{\circ}$ for a few seconds to sterilize. One part of concentrated solution was then added to nine parts of thick bacterial suspension and mixed thoroughly.

\section{Drying the bacterial suspension}

Drying in the unfrozen state in a desiccator over $\mathrm{P}_{2} \mathrm{O}_{5}$ in a partial vacuum. In early experiments the bacterial suspension was delivered into Petri dishes in $1 \mathrm{ml}$. quantities. But in the great majority of experiments it was delivered on to a sterile waxed surface as discrete drops by means of a 'standard' dropping pipette, calibrated to deliver 36 drops of water $/ \mathrm{ml}$. under controlled conditions. The waxed surface was made by dipping a filter paper into hot melted paraffin wax to sterilize, allowing to cool and placing in a Petri dish. In some tests the drops were delivered directly into one $\mathrm{ml}$. vials with wide necks. The samples were placed in a desiccator containing $\mathrm{P}_{2} \mathrm{O}_{5}$ and dried at a pressure of 100-300 mm. $\mathrm{Hg}$. Drying was continued with excess $\mathrm{P}_{2} \mathrm{O}_{5}$ for 2-3 days at room temperature, after which no further appreciable loss in weight was found to occur. Before opening, the desiccator was slowly filled with air filtered through sterile cotton-wool. On drying the drops formed thin disks of uniform size which were carefully scraped off the filter paper, transferred to a suitable sterile container and stored under a cotton-wool plug in a desiccator over $\mathrm{P}_{2} \mathrm{O}_{5}$, usually at low pressure. For subculture a disk was removed from the container by touching with a moistened platinum loop, to which it readily adhered, transferred to broth and warmed to redissolve. One loopful was then subcultured in fresh broth or on to a solid medium. There was little trouble with contamination of samples provided all possible aseptic precautions were taken during drying. Small numbers of contaminants present in the dried disk were presumably diluted out when it was redissolved and subcultured. The desiccators were stored at room temperature during the first 2-year period, namely, laboratory temperatures of $18-21^{\circ}$, except for brief periods during the summer months. During the second 2 years they were kept in a cool cellar at somewhat lower temperatures.

Drying by the lyophile process. The method of Flosdorf \& Mudd (1935) was used.

Drying by the McFarlane process. The McFarlane (1942-3) process differs from other freeze-drying processes in that the material to be dried is held frozen to a metal surface. A coil of tubing was used, through which brine was circulated at $-40^{\circ}$. Freezing was extremely rapid to ensure that the material remained homogeneous. The coil with the frozen material attached was lifted out of the container and transferred to a vessel containing a large outer coil through which brine was passed at $-50^{\circ}$. Brine at $-23^{\circ}$ was now passed through the inner coil. A high vacuum was applied and the water vapour condensed and was frozen on to the outer coil. When the material held on to the inner coil was completely dried it was transferred to a desiccator containing $\mathrm{P}_{2} \mathrm{O}_{5}$ and stored in vacuo. The fundamental difference between this process and the Flosdorf \& Mudd (1935) process lies in the fact that in the latter at a certain 
stage the heat lost by evaporation is less than that entering by radiation and conduction so that in the terminal stages the temperature in certain parts of the material being dried is bound to rise. In the McFarlane process this does not occur as a constant low temperature is maintained throughout by refrigeration.

\section{Estimation of percentage survival}

Viable counts were carried out on the undried and dried drops. Usually ten drops were pooled, the mean count/drop was determined and the percentage survival calculated. The surface viable count method modified from that described by Miles \& Misra (1938) was used. Under carefully standardized conditions and when adequate numbers of colonies were counted this gave results with a high degree of accuracy.

\section{RESULTS}

The effect of different suspending media and of reducing substances on survival rate; drying over $\mathrm{P}_{2} \mathrm{O}_{5}$ in vacuo

Melted nutrient gelatin was first selected as a suspending medium since it was thought that the gelatin and other substances present in the medium might coat the organisms protectively during drying. One-quarter strength Ringer solution was used for comparison. Ascorbic acid was also tested as it was considered that the death of organisms during drying and storage might in part be due to oxidation. Salmonella paratyphi B was used as the test organism.

Table 1. Showing the percentage survival of Salmonella paratyphi $B$ (Netherne) dried in melted $10 \%$ nutrient gelatin and in one-quarter strength Ringer solution, with and without the addition of ascorbic acid

\begin{tabular}{lcccc} 
& Dried & \multicolumn{2}{c}{ Stored 23 days } \\
\cline { 4 - 5 } Nutrient gelatin + ascorbic acid $0 \cdot 1 \%$ & 3 days & In desiccator & On bench \\
Nutrient gelatin - ascorbic acid & $53 \cdot 6$ & $35 \cdot 7$ & $17 \cdot 0$ \\
Ringer solution + ascorbic acid $0 \cdot 1 \%$ & $32 \cdot 1$ & $2 \cdot 8$ & $2 \cdot 7$ \\
Ringer solution - ascorbic acid & $5 \cdot 7$ & $1 \cdot 3$ & $0 \cdot 01$ \\
& $4 \cdot 4$ & $0 \cdot 003$ & $0 \cdot 001$
\end{tabular}

It will be seen (Table 1) that Salm. paratyphi B was more effectively preserved in $10 \%$ nutrient gelatin than in one-quarter strength Ringer solution, and that ascorbic acid was also beneficial, particularly on storage. The drop in survival rate was, as would be expected, less rapid in the desiccator at room temperature than on the bench. The results with other suspending media and with glutathione as a reducing agent are shown in Table 2. Nutrient gelatin was better than horse blood, serum, mucin or polyvinyl alcohol under the conditions of test. Furthermore, glutathione in the concentration used did not exert the beneficial action of ascorbic acid. Although these substances 
might have been investigated further and other suspending media and reducing agents tested, in view of the favourable results with nutrient gelatin and ascorbic acid it was decided to confine the study to these substances.

Fig. 1 shows the effect of varying the concentration of ascorbic acid from $0 \cdot 1$ to $2 \cdot 5 \%$ and of using nutrient gelatin diluted $1: 10$ with distilled water as suspending medium. The test organism was Chromobacterium prodigiosum.

Table 2. Showing the effect of drying different organisms in melted $10 \%$ nutrient gelatin, nutrient gelatin plus heated rabbit serum, defibrinated horse blood, mucin, or polyvinyl alcohol and the effect of adding ascorbic acid and glutathione

\begin{tabular}{|c|c|c|c|c|c|}
\hline Species & $\begin{array}{c}\text { Concentration } \\
\text { of cells } \\
\text { before } \\
\text { drying }\end{array}$ & $\begin{array}{l}\text { Concentration } \\
\text { of reducing } \\
\text { agent } \\
(\%)\end{array}$ & Suspending medium & $\begin{array}{l}\text { Time } \\
\text { of } \\
\text { drying }\end{array}$ & $\begin{array}{c}\text { Per- } \\
\text { centage } \\
\text { survival }\end{array}$ \\
\hline $\begin{array}{l}\text { Salm. para- } \\
\text { typhi } \mathbf{B}\end{array}$ & $4.0 \times 10^{10} / \mathrm{ml}$ & $\begin{array}{l}\text { Asc. acid } 0 \cdot 1 \\
\text { Glutathione } 0 \cdot 1 \\
\text { Nil } \\
\text { Asc. acid } 0 \cdot 1 \\
\text { Glutathione } 0 \cdot 1 \\
\text { Nil }\end{array}$ & $\begin{array}{l}\text { Defibrinated horse blood } \\
\text { Defibrinated horse blood } \\
\text { Defibrinated horse blood } \\
\text { Nutrient gelatin } \\
\text { Nutrient gelatin } \\
\text { Nutrient gelatin }\end{array}$ & 3 days & $\begin{array}{c}11 \cdot 25 \\
7 \cdot 5 \\
10 \cdot 0 \\
100 \cdot 0 \\
14 \cdot 7 \\
15 \cdot 7\end{array}$ \\
\hline $\begin{array}{l}\text { Shig. shigae } \\
\text { (K 624) }\end{array}$ & $1.0 \times 10^{9} /$ drop & $\begin{array}{l}\text { Asc. acid } 0.5 \\
\text { Asc. acid } 0.5\end{array}$ & $\begin{array}{l}\text { Nutrient gelatin } \\
\text { Nutrient gelatin } 1 \text { part } \\
+9 \text { parts heated rabbit } \\
\text { serum } \\
\text { Nutrient gelatin } 1 \text { part } \\
\text { +99 parts heated rabbit } \\
\text { serum }\end{array}$ & 24 hr. & $\begin{array}{l}81 \cdot 6 \\
30 \cdot 1\end{array}$ \\
\hline Bact. coli & $\begin{array}{l}1.2 \times 10^{9} / \text { drop } \\
1.6 \times 10^{9} / \text { drop }\end{array}$ & $\begin{array}{l}\text { Asc. acid } 0 \cdot 25 \\
\text { Asc. acid } 0 \cdot 25\end{array}$ & $\begin{array}{l}\text { Nutrient gelatin } \\
\text { Mucin } 2.5 \%\end{array}$ & 2 days & $\begin{array}{r}40 \cdot 5 \\
<1 \cdot 0\end{array}$ \\
\hline $\begin{array}{l}\text { Salm.typhi } \\
\text { ('T150) }\end{array}$ & $\begin{array}{l}1.73 \times 10^{9} / \text { drop } \\
1.57 \times 10^{9} / \text { drop }\end{array}$ & $\begin{array}{l}\text { Asc. acid } 0 \cdot 25 \\
\text { Asc. acid } 0 \cdot 25\end{array}$ & $\begin{array}{l}\text { Nutrient gelatin } \\
\text { Polyvinyl alcohol } 2.0 \%\end{array}$ & $24 \mathrm{hr}$. & $\begin{array}{l}19 \cdot 1 \\
14 \cdot 6\end{array}$ \\
\hline
\end{tabular}

The percentage survival increased with the concentration of ascorbic acid up to $0.5 \%$ and thereafter fell off; decreasing the concentration of nutrient gelatin gave somewhat lower survival rates. In other tests solutions of gelatin in concentrations higher than $10 \%$ gave no better result, and, moreover, were difficult to use owing to their high viscosity. Similar curves were obtained with Bacterium coli and Salmonella typhi-suis (Fig. 2). The deleterious effect of higher concentrations of ascorbic acid might be due to excessive acidity, since the $\mathrm{pH}$, as estimated roughly by indicator dyes, was $4.8-5 \cdot 2$ with $0.5 \%$, and $4 \cdot 4$ with $1 \%$ ascorbic acid.

Tests were made on Chromobacterium prodigiosum in nutrient gelatin with varying concentrations of ascorbic acid in which part of each suspension was first neutralized to $\mathrm{pH} 6 \cdot 8-7 \cdot 0$ with one or two drops of $\mathrm{N}-\mathrm{NaOH}$ before drying (Fig. 3). As anticipated, neutralized ascorbic acid was not deleterious in the higher concentrations. This fact has also been noted by H. B. Naylor (personal communication). In this test, as with Salmonella typhi-suis (Fig. 2), the optimal concentration was $0 \cdot 25 \%$; this concentration was used in nearly all the storage tests described below. Recently, however, a similar comparison of the effect produced by ascorbic acid and neutralized ascorbic acid in concen- 


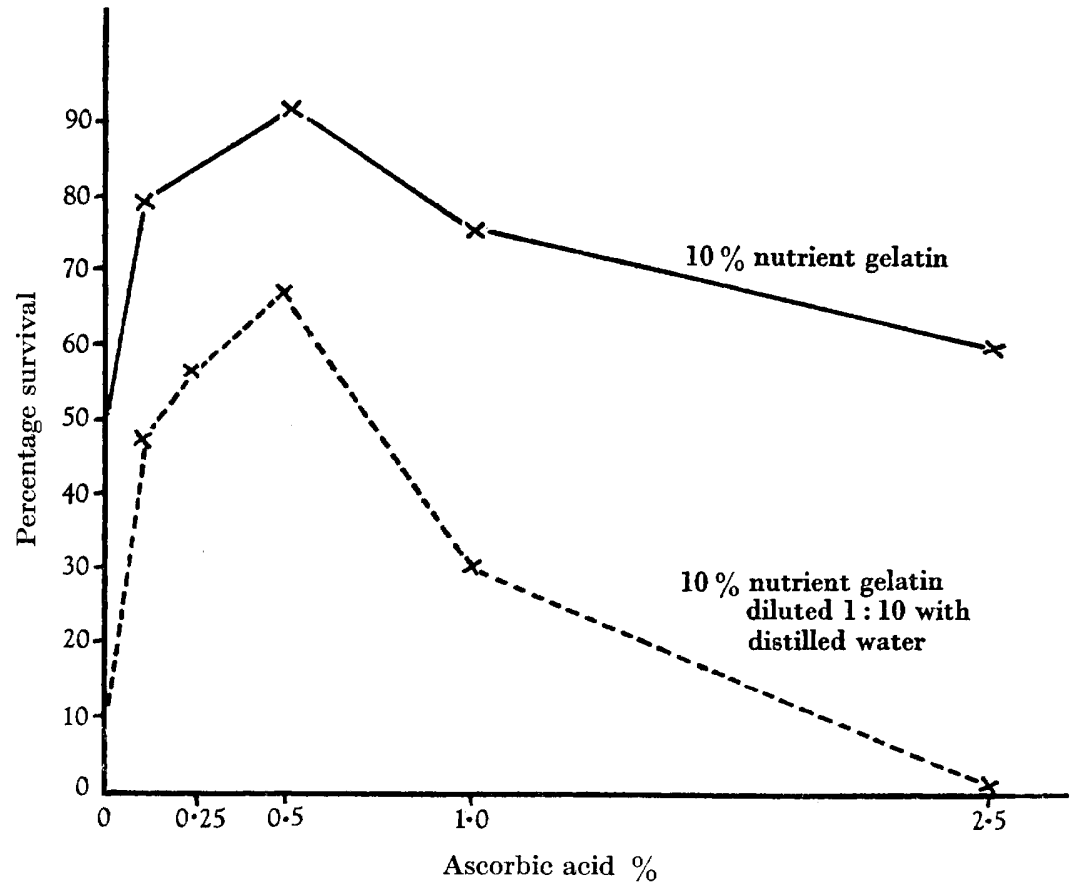

Fig. 1. The percentage survival of Chr. prodigiosum with varying concentrations of ascorbic acid after drying for $48 \mathrm{hr}$. in $10 \%$ melted nutrient gelatin and in the same medium diluted $1: 10$ with distilled water (concentration of viable cells/undried drop $=1.7 \times 10^{10}$ approx.)

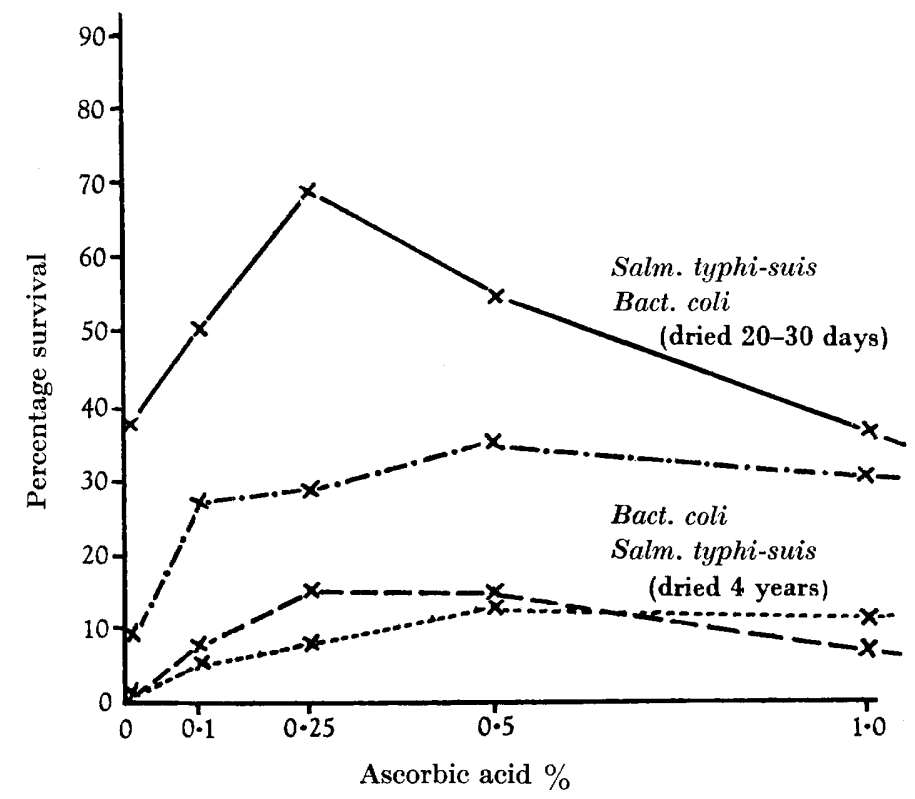

Fig. 2. The percentage survival of Salm. typhi-suis and Bact. coli with varying concentrations of ascorbic acid after drying for 3-4 weeks in melted $10 \%$ nutrient gelatin, and after storage for 4 years. (Concentration of viable cells/undried drop $=\mathbf{2 \cdot 2} \times 10^{8}$.) 
trations up to $\mathbf{0} \cdot \mathbf{2 5} \%$ has been made with a number of different species, most of which were more delicate than those investigated earlier. 'The more important results are tabulated in Table 3 .

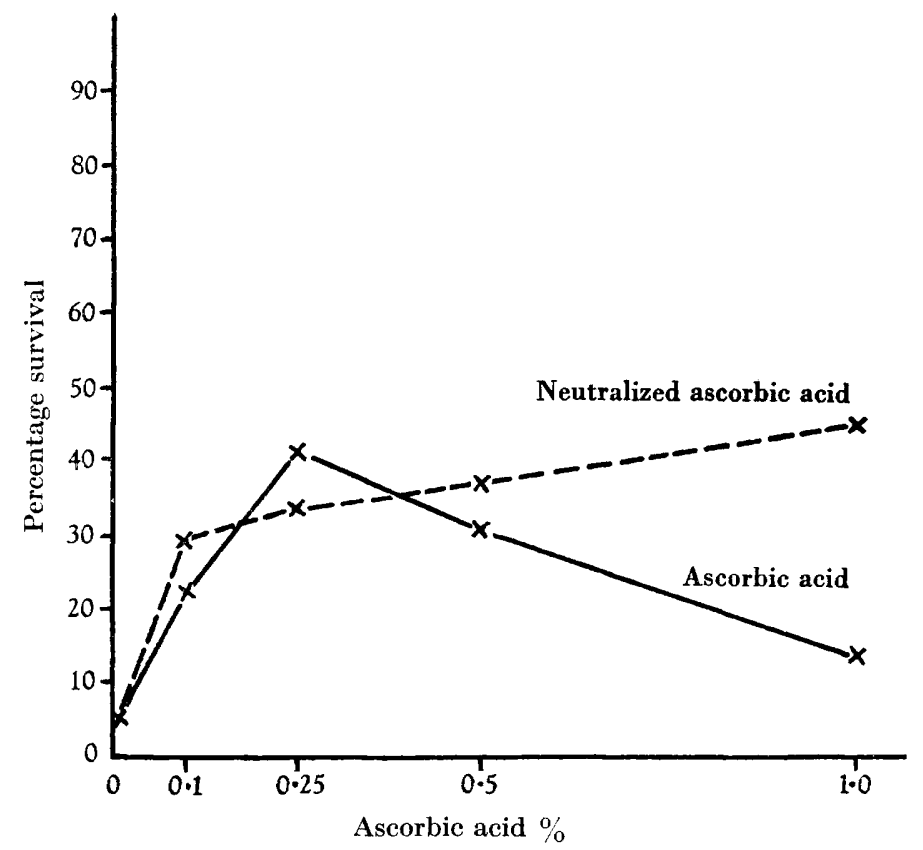

Fig. 3. The effect of neutralizing ascorbic acid with $\mathrm{NaOH}$ on survival rate of Chr. prodigiosum after drying for 9 days in melted $10 \%$ nutrient gelatin. (Concentration of viable cells/undried drop $=7 \cdot 3 \times 10^{8}$.)

Table 3. Showing the percentage survival obtained on drying different species over $\mathrm{P}_{2} \mathrm{O}_{5}$ in melted nutrient gelatin containing varying concentrations of ascorbic acid, unneutralized and neutralized with $\mathrm{NaOH}$

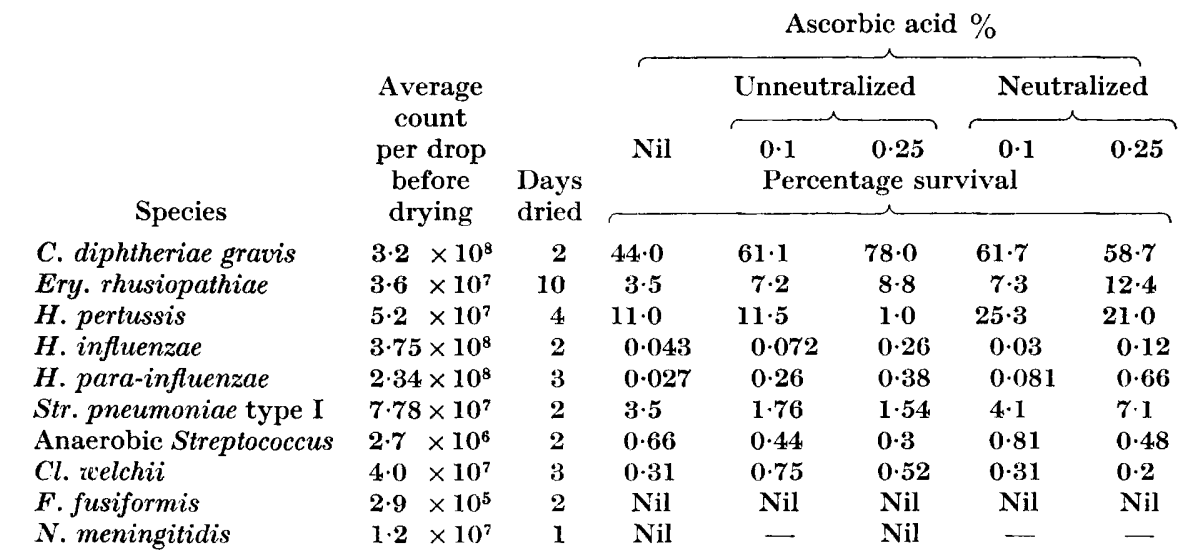

As might have been expected, the percentage survival values vary widely with the different species under test. With one species, Corynebacterium diphtheriae, the percentage survival rates are of the same order as those shown 
in Tables $\mathbf{1}$ and 2. With the exception of Haemophilus pertussis, the others are much less resistant to drying and two species, Neisseria meningitidis and Fusiformis fusiformis, failed altogether to grow on subculture. It should be noted that certain species, such as Haemophilus pertussis and Streptococcus pneumoniae, show an improvement only with neutralized ascorbic acid, presumably owing to the fact that they are particularly sensitive to acid. These results suggest that sodium ascorbate may be better than ascorbic acid for routine purposes.

\section{$A$ comparison of the slow drying process over $\mathrm{P}_{2} \mathrm{O}_{5}$ in vacuo with the rapid freeze-drying process}

The relative merits of these two processes have not hitherto been investigated in much detail. Chromobacterium prodigiosum was suspended in $10 \%$ nutrient gelatin containing $0.5 \%$ ascorbic acid. In the first experiment test samples of the material were dried simultaneously by the rapid freeze-drying lyophile process of Flosdorf \& Mudd and by the standard technique over $\mathrm{P}_{2} \mathrm{O}_{5}$ in vacuo. In the second test a comparison was made between the standard $\mathrm{P}_{2} \mathrm{O}_{5}$ method and the rapid freeze-drying process developed by McFarlane. The results are shown in Table 4.

Table 4. Comparing the survival rates obtained by rapid freeze-drying processes with those given by drying over $\mathrm{P}_{2} \mathrm{O}_{5}$ Chromobacterium prodigiosum in $10 \%$ nutrient gelatin with ascorbic acid $0.5 \%$

\begin{tabular}{lc}
\multicolumn{1}{c}{ Method of drying } & $\begin{array}{c}\text { Percentage } \\
\text { survival }\end{array}$ \\
$\mathrm{P}_{2} \mathrm{O}_{5}$ drying-48 hr. & $90 \cdot 2,86 \cdot 1$ \\
Freeze-drying (Flosdorf \& Mudd, 1938) & $33 \cdot 7,29 \cdot 6$ \\
$\mathrm{P}_{2} \mathrm{O}_{5}$ drying-48 hr. & $60 \cdot 7$ \\
Freeze-drying (A. S. McFarlane, 1942-3) & $\mathbf{2 3 \cdot 6}$
\end{tabular}

The survival values were approximately three times higher with $\mathbf{P}_{2} \mathrm{O}_{5}$ drying than with either method of lyophilization. As a result of these experiments and in view of its simplicity the slower drying method was adopted as a routine. It is, nevertheless, likely that with certain organisms, such as the meningococcus, lyophilization will prove to be the only satisfactory method, since (Table 3) Neisseria meningitidis failed to survive drying over $\mathrm{P}_{2} \mathrm{O}_{5}$ whereas it has been a general experience that it and the gonococcus will survive freezedrying, according to some workers for as long as 18 years (Elser et al. 1935).

The higher survival rates obtained with Chromobacterium prodigiosum by the slower drying process might in part be accounted for by some degree of growth during drying. Tests with $\mathrm{Chr}$. prodigiosum in nutrient gelatin showed that with the concentration employed $\left(10^{10}\right.$ organisms $/ \mathrm{ml}$. $)$ the count might increase slightly during the first $3 \mathrm{hr}$. of drying. The maximum increase obtained was $30 \%$, but it was usually less than this figure. In the presence of ascorbic acid this increase was never found to occur. The factor of growth therefore did not appear to play any substantial part in the results obtained. 


\section{Preservation of bacteria by drying}

In the experiments recorded in Table 4, the degree of drying by the different processes was measured. The weight of moisture removed by drying the drops to constant weight over $\mathrm{P}_{2} \mathrm{O}_{5}$ was $89 \cdot 4 \%$ of that of undried material. By the McFarlane freeze-drying technique the loss of weight was $90.1 \%$ of the total. It would appear, therefore, that the method giving the highest degree of desiccation does not necessarily give the most efficient results in preserving viability.

The preservation of viability on drying by the gelatin-ascorbic acid process and on storing for long periods over $\mathrm{P}_{2} \mathrm{O}_{5}$

A large number of different bacterial species, and in one or two cases, a number of strains of the same species, were dried in melted nutrient gelatin tascorbic acid over $\mathrm{P}_{2} \mathrm{O}_{5}$ and stored from $3 \cdot 5$ to 4.5 years. At the time these

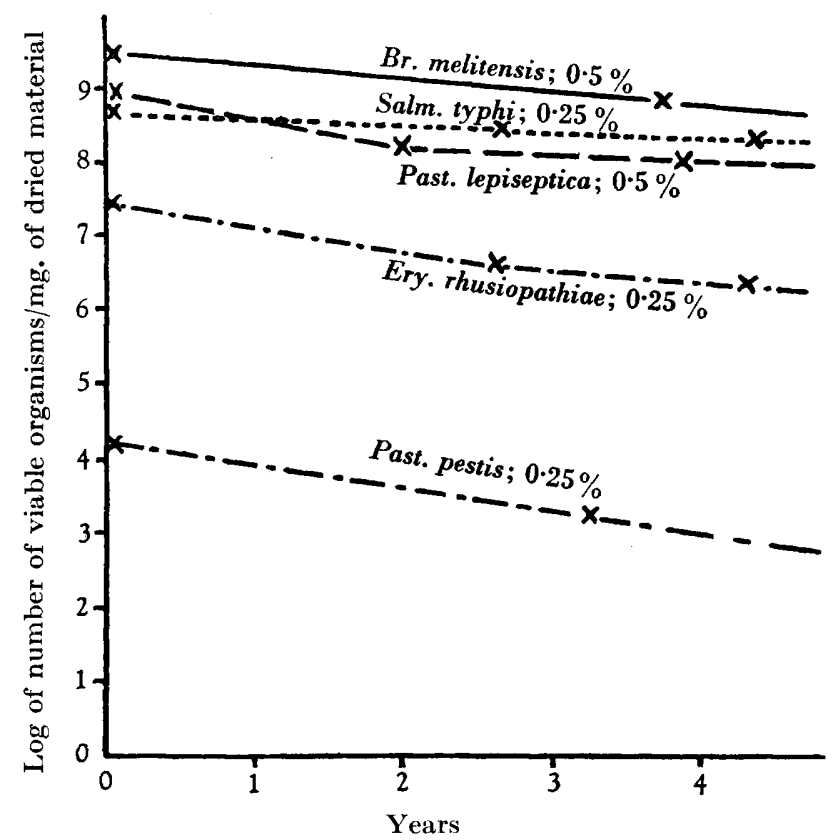

Fig. 4. The drop in viability of different species dried in melted $10 \%$ nutrient gelatin with 0.25 or $0.5 \%$ ascorbic acid and stored at room temperature over $\mathbf{P}_{2} \mathrm{O}_{5}$.

storage tests were set up the deleterious effect on an acid $\mathrm{pH}$ on certain species (Table 3) was not known, and nearly all tests were carried out with unneutralized ascorbic acid, usually in a concentration of $0.25 \%$. The results are recorded in Table 5 and Fig. 4 . It will be noted in Table 5 that the percentage survival immediately after drying varies from 90 to $12 \cdot 5 \%$, and after 4 years' storage from 50 to $1 \%$ with one exception, namely, Vibrio cholerae. Those species with the highest initial survival rate tended to die less rapidly than those with the lower initial survival rates. Thus the strains with an initial survival rate of $40 \%$ or over had in most cases fallen to about half their initial 
value in 2 years and to one-half to one-quarter in 4 years; for example, the majority of strains of Salmonellae, Shigella shigae, Chromobacterium prodigiosum and Streptococcus pyogenes.

Table 5. Showing the survival rates of different species immediately after drying over $\mathrm{P}_{2} \mathrm{O}_{5}$ in melted nutrient gelatin with ascorbic acid and after long periods of storage at room temperature

\begin{tabular}{|c|c|c|c|c|c|}
\hline Species & $\begin{array}{l}\text { Ascorbic } \\
\text { acid } \\
(\%)\end{array}$ & $\begin{array}{c}\text { Viable } \\
\text { organisms } \\
\text { per mg. of } \\
\text { dried material, } \\
\text { immediately } \\
\text { after drying }\end{array}$ & $\begin{array}{c}\text { Per- } \\
\text { centage } \\
\text { survival } \\
\text { imme- } \\
\text { diately } \\
\text { after } \\
\text { drying } \\
\text { (2-3 days) }\end{array}$ & $\begin{array}{c}\text { Per- } \\
\text { centage } \\
\text { survival } \\
\text { after } \\
\text { approx. } \\
2 \text { years' } \\
\text { storage }\end{array}$ & $\begin{array}{c}\text { Per- } \\
\text { centage } \\
\text { survival } \\
\text { after } \\
\text { approx. } \\
4 \text { years' } \\
\text { storage }\end{array}$ \\
\hline Salm. typhi (T 150) & $0 \cdot 5$ & $6 \cdot 7 \times 10^{8}$ & $69 \cdot 6$ & - & $50 \cdot 0$ \\
\hline Salm. typhi (T 150) & $0 \cdot 25$ & $5.5 \times 10^{8}$ & $75 \cdot 0$ & $34 \cdot 7$ & $21 \cdot 8$ \\
\hline Salm. typhi (T135) & $0 \cdot 25$ & $6.4 \times 10^{8}$ & $80 \cdot 6$ & $31 \cdot 5$ & $15 \cdot 6$ \\
\hline Salm. typhi ('T 137) & $0 \cdot 25$ & $4.0 \times 10^{8}$ & $48 \cdot 5$ & - & $18 \cdot 8$ \\
\hline Salm. typhi ('T 142) & $0 \cdot 25$ & $2.5 \times 10^{8}$ & $21 \cdot 7$ & - & $1 \cdot 3$ \\
\hline Salm. typhi (T 180) & $0 \cdot 25$ & $4.6 \times 10^{8}$ & $48 \cdot 9$ & - & $16 \cdot 7$ \\
\hline Salm. paratyphi $\mathrm{C}$ & 0.5 & $8.7 \times 10^{8}$ & $33 \cdot 0$ & 一 & $14 \cdot 0$ \\
\hline Salm. typhi-murium & $0 \cdot 25$ & 一 & - & $20 \cdot 0$ & $18 \cdot 4$ \\
\hline Salm. typhi-suis & $0 \cdot 25$ & $8.8 \times 10^{7}$ & $68 \cdot 4$ & $11 \cdot 5$ & $16 \cdot 2$ \\
\hline Salm. gallinarum . & 0.5 & $6.4 \times 10^{7}$ & $74 \cdot 1$ & $31 \cdot 8$ & $28 \cdot 4$ \\
\hline Bact. coli & $0 \cdot 5$ & $2 \cdot 3 \times 10^{7}$ & $25 \cdot 5$ & - & $12 \cdot 0$ \\
\hline $\begin{array}{l}\text { Shig. shigae (K624) } \\
\text { Shig. shigae (K 624) } \\
\text { Shig. shigae (S 19) }\end{array}$ & $\begin{array}{l}0 \cdot 25 \\
0 \cdot 5 \\
0 \cdot 25\end{array}$ & $\begin{array}{l}2 \cdot 3 \times 10^{8} \\
2 \cdot 9 \times 10^{8} \\
6 \cdot 2 \times 10^{7}\end{array}$ & $\begin{array}{l}36 \cdot 0 \\
22 \cdot 9 \\
38 \cdot 6\end{array}$ & $\frac{11 \cdot 3}{-}$ & $\begin{array}{r}4 \cdot 5 \\
4 \cdot 2 \\
10 \cdot 5\end{array}$ \\
\hline $\begin{array}{l}\text { Vibrio cholerae (Inada S) } \\
\text { Vibrio cholerae (Inada O) }\end{array}$ & $\begin{array}{l}0 \cdot 25 \\
0 \cdot 25\end{array}$ & $\begin{array}{l}3 \cdot 3 \times 10^{5} \\
1 \cdot 9 \times 10^{5}\end{array}$ & $\begin{array}{l}0 \cdot 13 \\
0 \cdot 15\end{array}$ & $\begin{array}{l}0 \cdot 0 \\
0 \cdot 0\end{array}$ & - \\
\hline Chr. prodigiosum & 0.5 & $6.0 \times 10^{8}$ & $71 \cdot 3$ & $26 \cdot 5$ & $16 \cdot 0$ \\
\hline Past. pestis (L 327) & $0 \cdot 25$ & $1 \cdot 6 \times 10^{4}$ & - & - & $\begin{array}{c}1 \cdot 0 \\
\text { (approx.) }\end{array}$ \\
\hline Past. pestis (L,337) & $0 \cdot 25$ & $1.6 \times 10^{4}$ & - & - & $\begin{array}{c}1 \cdot 0 \\
\text { (approx.) }\end{array}$ \\
\hline Past. pestis (Schütze) & $0 \cdot 1$ & $2 \cdot 0 \times 10^{3}$ & $12 \cdot 5$ & - & - \\
\hline Past. lepiseptica & 0.5 & $1.0 \times 10^{9}$ & $28 \cdot 0$ & $4 \cdot 9$ & $3 \cdot 3$ \\
\hline Br. melitensis (Mentone) & $0 \cdot 5$ & $2 \cdot 9 \times 10^{9}$ & $77 \cdot 0$ & - & $17 \cdot 3$ \\
\hline $\begin{array}{l}\text { Ery. rhusiopathiae } \\
\text { Ery. rhusiopathiae }\end{array}$ & $\begin{array}{l}0 \cdot 25 \\
0 \cdot 5\end{array}$ & $\begin{array}{l}2.6 \times 10^{7} \\
2.2 \times 10^{7}\end{array}$ & $\begin{array}{l}28 \cdot 3 \\
23 \cdot 0\end{array}$ & $4 \cdot 5$ & $\begin{array}{l}2 \cdot 6 \\
1 \cdot 2\end{array}$ \\
\hline Strep. pyogenes (Richards) & $0 \cdot 0$ & $1 \cdot 14 \times 10^{7}$ & $68 \cdot 6$ & $12 \cdot 6$ & $8 \cdot 6$ \\
\hline Strep. pyogenes (Richards) & $0 \cdot 25$ & $9.7 \times 10^{6}$ & $58 \cdot 0$ & $26 \cdot 1$ & $30 \cdot 3$ \\
\hline Strep. pyogenes (Richards) & $0 \cdot 25$ & $10^{6}$ approx. & - & $44 \cdot 0$ & $31 \cdot 4$ \\
\hline Strep. pyogenes (Richards) & $0 \cdot 25$ & $1.2 \times 10^{5}$ & $91 \cdot 0$ & $72 \cdot 7$ & $48 \cdot 5$ \\
\hline Strep. pyogenes (Richards) & $0 \cdot 25$ & $10^{4}$ approx. & - & $62 \cdot 0$ & $65 \cdot 7$ \\
\hline
\end{tabular}

Those with lower initial figures of $12-30 \%$ (as, for example, Erysipelothrix rhusiopathiae and Pasteurella pestis) have in most cases fallen to one-tenth to one-twentieth of the initial figure in 4 years. Vibrio cholerae, with the lowest initial survival rate recorded in this series $(0 \cdot 1 \%)$, failed to grow when tested a few months later. Different strains of the same species, i.e. Salmonella typhi, 
differed markedly in initial survival rates. The strains tested were all freshly isolated from fatal cases and were tested under identical conditions. The initial survival rates were $40 \%$ or over, but with one strain (T 142) it was about $20 \%$. Other typhoid strains, e.g. Ty 2 and $\mathrm{T} 1$ (not included in Table 5), also gave lower figures, varying from 6 to $25 \%$. An old laboratory stock strain, Ty Oxford, gave on a number of occasions initial survival values varying from 50 to $30 \%$. It is evident that considerable variation in resistance to drying exists among different strains of typhoid bacilli, and the same may well be true for other species.

An indication of the effect of varying the cell concentration is seen with Streptococcus pyogenes. With a diminution in cell concentration, the percentage survival rate rises. A similar effect has been noted with Pasteurella pestis and Salmonella typhi-murium. The advantage gained in this way, however, is not marked and in order to obtain as high a number as possible of viable organisms in the dried material it is necessary to use highly concentrated suspensions. Fig. 4 shows the large numbers of organisms surviving in the dried samples over a 4-year period. It indicates that with a number of species, positive subcultures may be expected for a very long further period if the same conditions of storage are maintained.

\section{The preservation of virulence}

A number of pathogenic species, included in the above series, were tested for virulence before drying, and after drying and storing for 4 years (Table 6). Though the tests were incomplete and in most cases on a small scale there is some indication of the degree to which virulence has been maintained. Virulence has on the whole been extremely well preserved with the six species tested, which include some which are notoriously difficult to maintain in a virulent state. The results with the Pasteurella group are particularly satisfactory. The two typhoid strains were also tested for Vi-antigen by agglutination after storage and both agglutinated to titre with a pure Viantiserum.

\section{DISCUSSION}

The experiments provide a considerable amount of information about the factors which influence survival of bacteria on drying, measured in terms of the percentage survival rates estimated by a series of viable counts of the cultures tested.

In the first place the medium is important. Of the different suspending media tested melted nutrient gelatin was the most satisfactory. The constituents of this medium, namely, gelatin, Lemco beef extract and peptone, were not tested separately in any detail, but there is some evidence that the beneficial effect is mainly due to the gelatin (H. B. Naylor, personal communication).

A favourable effect on the survival of many species was also produced by ascorbic acid in certain concentrations. Cysteine and thiourea are said to 
produce a similar effect (H. B. Naylor, personal communication). These substances presumably counteract oxidation harmful to survival. Glutathione, however, in a single experiment was found to be inactive. Above concentrations of $0.25-0.5 \%$ the favourable effect of ascorbic acid is more than counterbalanced by the inimical effects of acid $\mathrm{pH}$ unless the acid be neutralized.

Table 6. Showing the results of virulence tests on a number of pathogenic species before drying and after drying and storing for approximately four years

\begin{tabular}{|c|c|c|c|c|c|}
\hline \multirow[b]{2}{*}{ Species } & \multirow{2}{*}{$\begin{array}{l}\text { Observa- } \\
\text { tion } \\
\text { period } \\
\text { after } \\
\text { infection } \\
\text { (days) }\end{array}$} & \multicolumn{2}{|c|}{$\begin{array}{l}\text { Virulence test } \\
\text { before drying }\end{array}$} & \multicolumn{2}{|c|}{$\begin{array}{l}\text { Virulence test after } \\
\text { drying and storing } \\
\text { for about } 4 \text { years }\end{array}$} \\
\hline & & $\begin{array}{l}\text { Infecting } \\
\text { dose }\end{array}$ & $\begin{array}{l}\text { Animals } \\
\text { killed }\end{array}$ & $\begin{array}{l}\text { Infecting } \\
\text { dose }\end{array}$ & $\begin{array}{c}\text { Animals } \\
\text { killed }\end{array}$ \\
\hline Past. pestis & 14 & $\begin{array}{l}0.5 \mathrm{ml} \text {. of } 10^{-7} \\
\text { dilution of } \\
\text { blood-broth } \\
\text { culture, i.p. }\end{array}$ & $\begin{array}{l}\text { Mice killed } \\
\text { regularly }\end{array}$ & $\begin{array}{l}0.5 \mathrm{ml} \text {. of } 10^{-7} \\
\text { dilution of } \\
\text { blood-broth } \\
\text { culture, i.p. } \\
\text { Do. } 10^{-6} \text { dilu- } \\
\text { tion }\end{array}$ & $0 / 10$ mice \\
\hline Past. lepiseptica & 7 & $\begin{array}{l}100 \text { approx., } \\
\text { i.v. }\end{array}$ & $3 / 6$ rabbits & $\begin{array}{l}300 \text { approx., } \\
\text { i.v. } \\
\text { 3000 approx., } \\
\text { i.v. }\end{array}$ & $\begin{array}{l}2 / 6 \text { rabbits } \\
6 / 6 \text { rabbits }\end{array}$ \\
\hline Ery. rhusiopathiae & 11 & $\begin{array}{l}0.5 \mathrm{ml} \text {. of } 10^{-5} \\
\text { dilution of } \\
\text { broth eulture, } \\
\text { i.p. }\end{array}$ & $5 / 5$ mice & $\begin{array}{l}0.5 \mathrm{ml} \text {. of } 10^{-4} \\
\text { dilution of } \\
\text { broth culture, } \\
\text { i.p. }\end{array}$ & 6/10 mice \\
\hline $\begin{array}{l}\text { Strep. pyogenes } \\
\text { (Richards) }\end{array}$ & 10 & $\begin{array}{l}10,000 \text { clumps } \\
\text { approx., i.p. }\end{array}$ & $27 / 30$ mice & $\begin{array}{l}10,000 \text { clumps } \\
\text { approx., i.p. }\end{array}$ & $9 / 10$ mice \\
\hline $\begin{array}{l}\text { Salm. typhi ('T 135) } \\
\text { Salm. typhi ('T 150) }\end{array}$ & 7 & $\begin{array}{l}9 \times 10^{7}, \text { i.p. } \\
1.5 \times 10^{8}, \text { i.p. }\end{array}$ & $\begin{array}{l}5 / 5 \text { mice } \\
5 / 10 \text { mice }\end{array}$ & $\begin{array}{l}2.2 \times 10^{8}, \text { i.p. } \\
2 \cdot 0 \times 10^{8}, \text { i.p. }\end{array}$ & $\begin{array}{l}5 / 5 \text { mice } \\
1 / 5 \text { mice }\end{array}$ \\
\hline $\begin{array}{l}\text { Salm. typhi- } \\
\text { murium }\end{array}$ & 21 & $\begin{array}{l}1 \cdot 1 \times 10^{5}, \text { i.p. } \\
1 \cdot 1 \times 10^{4}, \text { i.p. } \\
1 \cdot 1 \times 10^{3} \text {, i.p. } \\
1 \cdot 1 \times 10^{2} \text {, i.p. }\end{array}$ & $\begin{array}{l}5 / 6 \text { mice } \\
4 / 6 \text { mice } \\
4 / 6 \text { mice } \\
3 / 6 \text { mice }\end{array}$ & $\begin{array}{l}4.6 \times 10^{5}, \text { s.c. } \\
4.6 \times 10^{4}, \text { s.c. } \\
4.6 \times 10^{3} \text {, s.c. }\end{array}$ & $\begin{array}{l}9 / 10 \text { mice } \\
7 / 10 \text { mice } \\
5 / 10 \text { mice }\end{array}$ \\
\hline
\end{tabular}

i.p. $=$ intraperitoneal route; i.v. $=$ intravenous route; s.c. $=$ subcutaneous route.

With some particularly acid-sensitive species, e.g. Streptococcus pneumoniae and Haemophilus pertussis, even concentrations of $0 \cdot 1-0 \cdot 25 \%$ are deleterious, and an improvement in survival rate has only been brought about with neutralized ascorbic acid. It has yet to be determined whether sodium ascorbate is as effectivè as ascorbic acid in preserving viability on storage over long periods. With many species the survival rate with ascorbic acid in optimal concentration is 2-4 times that of control suspensions immediately after drying and from two hundred to ten thousandfold after storage for 4 years. With a few species, e.g. Streptococcus pyogenes, little or no improvement was apparent immediately after drying. After storage for 4 years, however, there was a tenfold advantage in the presence of ascorbic acid.

Another factor of importance is the method of drying. Slow drying over 
$\mathrm{P}_{2} \mathrm{O}_{5}$ gave better results than freeze-drying when a direct comparison was made with Chromobacterium prodigiosum as test organism suspended in gelatin and ascorbic acid. Similar comparisons are required with other species. Slow drying proved unsatisfactory for preserving a few species such as Neisseria meningitidis, Vibrio cholerae and Fusiformis fusiformis. On the other hand, Herta Schwabacher (personal communication) found that eight strains of $F$. fusiformis survived slow drying in gelatin ascorbic acid. Six of these strains had previously failed to survive freeze-drying. Neisseria meningitidis and $N$. gonorrhoeae were successfully preserved by freeze-drying (Elser et al. 1935). Results with these organisms might well be improved by using gelatin ascorbic acid as suspending medium. It is likely that with many organisms, particularly the more delicate ones, ad hoc modifications in the technique for the different species will greatly improve the survival rate.

Lyophilization gives a slightly higher degree of desiccation than does drying over $\mathrm{P}_{2} \mathrm{O}_{5}$. In the latter process the material is in the form of thin disks; it may be that in these the drying is not uniform throughout and that in the interior, where there may be more residual moisture, conditions are more favourable for survival. In addition to the factors considered above there are others which may influence bacterial survival on drying. Further studies are required of the effect of varying the preparation of cell suspensions, comparing growths of different ages on solid media, and in static and aerated fluid media. The nature of the gaseous environment and other physical conditions under which the cells are dried may also be of importance.

It is noteworthy that with the gelatin ascorbic acid $\mathrm{P}_{2} \mathrm{O}_{5}$ method, unlike others previously described, storage in a high vacuum appears to be unimportant. This may be due to the presence of reducing substances in the dried material. It was, however, found essential to maintain a completely dry atmosphere. An accurate comparison of the results of these drying experiments with those of other workers is difficult owing to the fact that in very few cases previously have percentage survival rates been estimated. Otten (1932), using saline as a suspending medium and drying over $\mathrm{H}_{2} \mathrm{SO}_{4}$, found the following survival rates immediately after drying: Salmonella typhi $2 \cdot 5-5 \%$; Shigella shigae $0.5 \%$ or less; Vibrio cholerae $0.05 \%$. He also stated that 'pneumococci, gonococci and meningococci were far under $1 \%$ and the same is the case for most of the other pathogenic bacteria such as Brucella melitensis, Br. abortus, Pasteurella pestis, Haemophilus influenzae and $H$. pertussis'. He noted a considerable improvement when meat extract was used in place of saline as the suspending medium, but no figures were given.

In addition to viability and virulence, properties such as chromogenicity were well preserved. In general, with nearly all species the organisms appeared to be maintained in a healthy condition in the dried material, as judged by the prompt and uniform development of colonies when subcultured directly on to an optimal medium. The gelatin ascorbic acid method is likely to be of considerable value for the maintenance of stock cultures of most bacterial species, especially those liable to undergo dissociation, such as phase I strains of Haemophilus pertussis and Vi strains of Salmonella typhi. It may also 
be found possible to apply this process to the preservation of living vaccines of organisms like avirulent Pasteurella pestis (Otten, 1936, 1941; Robic \& Minec, 1938) and Brucella abortus S 19 (Haring, 1938, 1939; Haring \& Traum, 1937, 1941; McEwen, 1941; Huddleson, 1942). The organisms might be dried in ampoules and the suspensions reconstituted as required by the addition of warm sterile diluent. The dosage required at different periods after drying could be determined from a graph, should the fall in viability be found to be consistent under standardized conditions of storage.

The freeze-drying experiments were carried out in collaboration with Dr D. W. Henderson and Dr A. S. McFarlane. My thanks are due to the numerous persons who kindly supplied me with many of the strains used. I am indebted to the Chief Scientist, Ministry of Supply, for permission to publish this work.

\section{REFERENCES}

Brown, J. H. (1925). The preservation of bacteria in vacuo. I. Abstr. Bact. 9, 8. Brown, J. H. (1932). The preservation of bacteria in vacuo. II. J. Bact. 23, 44.

Elser, W. J., Thomas, R. A. \& Steffen, G. I. (1935). The desiccation of sera and other biological products (including mieroörganisms) in the frozen state with preservation of the original qualities of products so treated. J. Immunol. 28, 433 .

Flosdorf, E. W. \& MudD, S. (1935). Procedure and apparatus for preservation in 'lyophile' form of serum and other biological substances. J. Immunol. 29, 389.

Flosdorf, E. W. \& MUdD, S. (1938). An improved procedure and apparatus for preservation of sera, microörganisms and other substances-the CryochemProcess. J. Immunol. 34, 469.

Gladstone, G. P. \& Fildes, P. (1940). Simple culture medium for general use without meat extract or peptone. Brit. J. exp. Path. 21, 161.

HARING, C. M. (1938). Vaccination against Bang's disease in an infected herd with U.S. Bureau of Animal Industry Brucella abortus strain 19. J. Amer. med. vet. Ass. $92,52$.

HARING, C. M. (1939). Results of vaccination with Brucella abortus strain 19 in an infected herd. J. Amer. med. vet. Ass. 94, 587.

Haring, C. M. \& Traum, J. (1937). Observations of pathogenic and antigenic effects of Brucella abortus U.S. Bureau of Animal Industry strain 19. J. agric. Res. $55,117$.

Haring, C. M. \& Traum, J. (1941). Vaccination to control brucellosis in cattle. J. Amer. med. vet. Ass. 98, 278.

Harris, M. M. \& LANGe, L. B. (1933). A note on the preservation of acid-fast bacteria in vacuo. J. lab. clin. Med. 18, 1066.

Herm, L. (1905). Die Widerstandsfähigkeit verschiedener Bakterienarten gegen Trocknung und die Aufbewahrung bakterienhaltigen Materials insbesondere beim Seuchendienst und für gerichtlich-medizinische Zwecke. Z. Hyg. InfektKr. $50,123$.

Heim, L. (1907). Ueber Pneumoniecoccen. Dtsch. med. Wschr. 33, 1587.

Heim, L. (1922). Lehrbuch der Bakteriologie, Aufl. 7, 228. Stuttgart: Enke.

Huddeson, I. F. (1942). Immunity in brucellosis. Bact. Rev. 6, 111.

McEwen, A. D. (1941). Experiments on contagious abortion. Vet. Rec. 53, 237.

McFarlane, A. S. (1942-3). Drying of foodstuffs in the frozen state. Proc. Brit. Ass. Refrig. 39, 69.

Mackie, T. J. \& MCCartney, J. E. (1945). Handbook of practical bacteriology, 7th ed. p. 181. Edinburgh: Livingstone. 
Miles, A. A. \& Misra, S. S. (1938). Estimation of the bactericidal power of the blood. J. Hyg., Camb., 38, 732.

Monton, H. E. \& Pulaski, E. J. (1938). Preservation of bacterial cultures. I. J. Bact. $35,163$.

Otтеn, L. (1930). Die Trockenkonservierung von pathogenen Bakterien. Zbl. Bakt. (I. Abt. Orig.) 116, 199.

Otren, L. (1932). Tr. Far East Ass. trop. Med., 8th Congr. Bangkok, 1930, p. 89.

OTTEN, L. (1936). Immunization against plague with live vaccine. Ind. J. med. Res. 24, 73.

Otten, L. (1941). Live plague vaccine and results. Meded. Dienst. Volksgezondh. Ned.-Ind. 30, 61.

Pauli, P. (1932). A propos d'un procédé facile pour la conservation des microorganismes à l'état de vie latente. Boll. Sez. ital. Soc. int. Microbiol. 4, 239.

Robic, J. \& Mrnec (1938). Note sur un cas de peste bubonique compliqué de pyomyosite à bacille de Yersin. Bull. Soc. Path. exot. 31, 679 .

Rogers, L. A. (1914). The preparation of dried cultures. J. infect. Dis. 14, 100.

Shackelt, L. F. (1909). An improved method of desiccation with some applications to biological problems. Amer. J. Physiol. 24, 325.

SwIFT, H. F. (1921). Preservation of stock cultures of bacteria by freezing and drying. J. exp. Med. 33, 69.

SwiFT, H. F. (1937). Simple method for preserving bacterial cultures by freezing and drying. J. Bact. 33, 411.

(Received 16 December 1946)

\begin{abstract}
ADDENDUM
At the time of going to press H. B. Naylor \& P. A. Smith have published a paper (1946, J. Bact. 52, 565) on the drying of Serratia marcescens (Chromobacterium prodigiosum) which embodies the personal communications of $\mathbf{H}$. B. Naylor referred to in the text. The greater part of the data presented above was available to these workers, who found that gelatin could be replaced by dextrin, pectin or Marmite without affecting the survival rate. Very high survival rates were obtained when the organisms from $24 \mathrm{hr}$. aerated cultures were suspended in a solution containing ascorbic acid, thiourea, ammonium chloride and dextrin at $\mathrm{pH} \mathrm{6-7}$ and dried by lyophilization.
\end{abstract}

